\title{
Correction: Desmosomal cadherins in zebrafish epiboly and gastrulation
}

\author{
Alexander Goonesinghe*, Xing-Ming Luan, Adam Hurlstone and David Garrod
}

After the publication of this work [1], we were alerted to an error contained therein that we would hereby like to correct. In our study, we refer to two zebrafish paralogues of desmoglein (Dsg), which we label alpha and beta. We state in the text that they are encoded by ENSDARG00000062750 and ENSDARG00000076426 respectively. In truth, the protein sequence we describe as Dsg $\alpha$ is encoded by ENSDARG00000076945. ENSDARG00000062750 corresponding to position $16,990,224-17,010,459$ on the reverse strand of chromosome 20 appears to encode a further Dsg paralogue, which we have not analysed any further.

We conclude that the zebrafish genome contains at least two and probably three genes encoding desmoglein paralogues.

We regret any inconvenience that this error might have caused. We wish to thank Dr. Alex Horby Christensen for bringing this matter to our attention.

Received: 24 January 2014 Accepted: 12 February 2014

Published: 11 March 2014

\section{Reference}

1. Goonesinghe A, Luan XM, Hurlstone A, Garrod D: Desmosomal cadherins in zebrafish epiboly and gastrulation. BMC Dev Biol 2012, 12:1.

\section{doi:10.1186/1471-213X-14-13}

Cite this article as: Goonesinghe et al: Correction: Desmosomal cadherins in zebrafish epiboly and gastrulation. BMC Developmental Biology 2014 14:13.

\section{Submit your next manuscript to BioMed Central and take full advantage of:}

- Convenient online submission

- Thorough peer review

- No space constraints or color figure charges

- Immediate publication on acceptance

- Inclusion in PubMed, CAS, Scopus and Google Scholar

- Research which is freely available for redistribution

* Correspondence: alexander.goonesinghe@astrazeneca.com

Faculty of Life Sciences, University of Manchester, Michael Smith Building,

Oxford Road, Manchester M13 9PT, UK

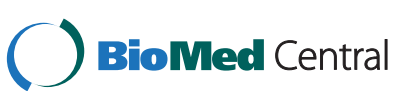

(c) 2014 Goonesinghe et al.; licensee BioMed Central Ltd. This is an Open Access article distributed under the terms of the Creative Commons Attribution License (http://creativecommons.org/licenses/by/2.0), which permits unrestricted use, distribution, and reproduction in any medium, provided the original work is properly credited. The Creative Commons Public Domain Dedication waiver (http://creativecommons.org/publicdomain/zero/1.0/) applies to the data made available in this article, unless otherwise stated. 